\title{
ANALISIS AKTIVITAS ANTIOKSIDAN SEDIAAN PROPOLIS YANG BEREDAR DI KOTA MAKASSAR DENGAN METODE FRAP \\ (Ferric Reducing Antioxidant Power)
}

\author{
Mamat Pratama, A. Muflihunna, Nurazizah Octaviani \\ Fakultas Farmasi Universitas Muslim Indonesia \\ Email : mamatpratamas.farm@gmail.com
}

\begin{abstract}
Antioxidants are chemical compounds that can donate one or more electrons to free radical, so that free radicals that can be suppressed.This study aimed to obtain and provide scientific evidence to the public regarding the antioxidant activity in propolis liquid product circulating in Makassar. This study using FRAP (Ferric Reducing Antioxidant Power) and 96\% ethanol. Free radical activity absorbance was measured with a UV-VIS spectrophotometer at a wavelength of $710 \mathrm{~nm}$ and the total value of antioxidant activity was calculated based on data absorbance. The calculations show that the sample $A$ has antioxidant activity of $0.0971 \mathrm{mgAAE} / \mathrm{mg}$ sample, the sample $B$ has antioxidant activity of $0.0669 \mathrm{mgAAE} / \mathrm{mg}$ sample, the sample $C$ has antioxidant activity of $0.0493 \mathrm{mgAAE} / \mathrm{mg}$ samples.
\end{abstract}

Key words: Antioxidants, FRAP (Ferric Reducing Antioxidant Power), Propolis Liquid Products.

\section{PENDAHULUAN}

Surah An Nahl ayat 69:

$$
\begin{aligned}
& \text { ثُُّمَ كُلِي مِنْ كُلِّ التََّّرَ اتِ فَاسْلْكِي }
\end{aligned}
$$

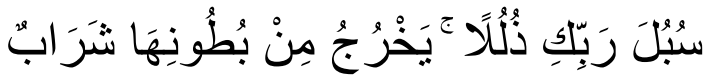

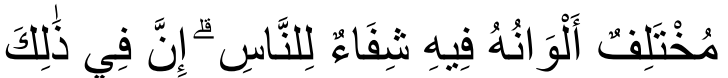

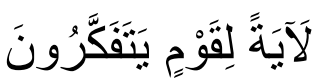

$$
\begin{aligned}
& \text { Terjemahan: "Kemudian }
\end{aligned}
$$

menyembuhkan bagi manusia.

Sesungguhnya pada yang demikian itu benar-benar terdapat tanda kebesaran Tuhan bagi orang yang memikirkan" [QS. An-Nahl : 69].

Antioksidan adalah senyawa yang dapat menyumbangkan satu atau lebih elektron kepada radikal bebas, sehingga radikal bebas tersebut dapat diredam. Tubuh manusia tidak mempunyai cadangan antioksidan dalam jumlah berlebih, sehingga jika terjadi paparan radikal berlebih maka tubuh membutuhkan antioksidan 
Analisis aktivitas antioksidan sediaan propolis yang beredar di kota makassar dengan metode FRAP (Ferric Reducing Antioxidant Power)

eksogen. Adanya kekhawatiran akan kemungkinan efek samping yang belum diketahui dari antioksidan sintetik menyebabkan antioksidan alami menjadi alternatif yang sangat dibutuhkan. ${ }^{1}$

Salah satu bahan yang mempunyai kandungan aktivitas antioksidan tinggi adalah propolis. Propolis adalah salah satu sumber zat gizi alami dan nutraceutical yang berasal dari substrat resin yang dikumpulkan lebah dari sari tunas daun dan kulit batang tanaman yang dicampur dengan enzim dan lilin dari sarang lebah. Salah satu kandungan senyawa kimia yang penting pada propolis adalah flavonoid. Flavonoid dilaporkan mempunyai potensi sebagai antioksidan kuat. Kandungan antioksidan dari propolis diduga dapat mencegah terjadinya stres oksidatif, sehingga dapat digunakan untuk mencegah timbulnya beberapa penyakit. ${ }^{2,3}$

Berdasarkan penelitian yang dilakukan oleh Saharuddin yang telah melakukan pengujian aktivitas antioksidan produk cair propolis yang beredar di kota Makassar menggunakan metode DPPH diperoleh hasil sampel propolis $A$ memiliki aktivitas antioksidan sedang dengan nilai $\mathrm{IC}_{50}$ sebesar $87,6 \mu \mathrm{g} / \mathrm{mL}$, sampel propolis $\mathrm{C}$ memiliki aktivitas antioksidan lemah dengan nilai $\mathrm{IC}_{50}$ sebesar 105,9 $\mu \mathrm{g} / \mathrm{mL}$ sedangkan sampel propolis $B$ dengan nilai $I_{50}$ sebesar $98.237,6 \mu \mathrm{g} / \mathrm{mL}$ dinyatakan tidak aktif. ${ }^{4}$

Hal inilah yang menjadi dasar peneliti melakukan uji aktivitas antioksidan sediaan propolis yang beredar di kota Makassar dengan menggunakan metode FRAP. Kelebihan metode FRAP yaitu metodenya yang murah, cepat dan reagen yang digunakan cukup sederhana.

\section{METODE PENELITIAN}

\section{Alat Dan Bahan}

Alat yang digunakan yaitu corong, gelas kimia (Iwaki Pyrex), labu tentukur (Iwaki Pyrex), pipet skala, pipet volume, rak tabung, sendok tanduk, batang pengaduk, timbangan analitik, spektrofotometer UV-Visible, oven, tabung reaksi (Iwaki Pyrex), sonikator, $\mathrm{pH}$ meter, mikropipet, dan erlenmeyer.

Bahan yang digunakan yaitu sediaan propolis $A, B$, dan $C$, aquades, asam trikloroasetat $10 \%$, $\mathrm{FeCl}_{3} \quad 0,1 \%$, dapar fosfat $(0,2 \mathrm{M}$ $\mathrm{pH}=6,6)$, etanol $96 \%$, kalium ferrisianida $1 \%$, asam oksalat $1 \%$, 
Analisis aktivitas antioksidan sediaan propolis yang beredar di kota makassar dengan metode FRAP (Ferric Reducing Antioxidant Power)

asam askorbat, aluminium foil dan tissu

\section{Prosedur Penelitian}

Pembuatan larutan dan penentuan aktivitas ntioksidan dengan metode FRAP $^{5}$

\section{Pembuatan Larutan $\mathrm{K}_{3} \mathrm{Fe}(\mathrm{CN})_{6} 1 \%$}

Larutan disiapkan dengan melarutkan 1 gram kalium ferrisianida dalam aquadest dan diencerkan dalam labu takar $100 \mathrm{~mL}$.

\section{Pembuatan Larutan TCA $10 \%$}

Larutan disiapkan dengan melarutkan 10 gram TCA dalam aquades dan diencerkan dalam labu takar $100 \mathrm{~mL}$.

\section{Pembuatan Larutan $\mathrm{FeCl}_{3}$ 0,1\% 6}

Larutan disiapkan dengan melarutkan 0,1 gram $\mathrm{FeCl}_{3}$ dalam aquades dan diencerkan dalam labu takar $100 \mathrm{~mL}$.

\section{Pembuatan Larutan Asam Oksalat 1} $\%$

Larutan disiapkan dengan melarutkan 1 gram asam oksalat dalam air bebas $\mathrm{CO}_{2}$ dan diencerkan dalam labu takar $100 \mathrm{~mL}$.

Pembuatan Larutan Dapar Fosfat 0,2 M pH 6,6

Larutan disiapkan dengan menimbang 2 gram $\mathrm{NaOH}$ dan dilarutkan dengan aquades bebas $\mathrm{CO}_{2}$ hingga tepat $250 \mathrm{~mL}$ dalam labu takar. Kemudian sebanyak 6,8 gram $\mathrm{KH}_{2} \mathrm{PO}_{4}$ yang dilarutkan dengan aquades bebas $\mathrm{CO}_{2} 250 \mathrm{~mL}$ dalam labu takar. Kemudian dipipet sebanyak 16,4 mL $\mathrm{NaOH}$ dimasukkan dalam labu takar dan dicampurkan $50 \mathrm{~mL} \quad \mathrm{KH}_{2} \mathrm{PO}_{4}$, selanjutnya diukur sampai $\mathrm{pH} \quad 6,6$ menggunakan $\mathrm{pH}$ meter dan dicukupkan dengan aquades bebas $\mathrm{CO}_{2}$ hingga $200 \mathrm{~mL}$.

\section{Pembuatan Larutan Standar Asam} Askorbat

Larutan stok 1000 ppm dibuat dengan melarutkan $25 \mathrm{mg}$ asam askorbat yang dilarutkan dengan asam oksalat 1\% hingga batas labu ukur 25 $\mathrm{mL}$. Selanjutnya dari larutan stok 1000 ppm diambil masing-masing 0,5; 0,6; 0,7; 0,8; 0,9 dan $1 \mathrm{~mL}$ dan ditempatkan dalam labu ukur $10 \mathrm{~mL}$ yang berbeda dan diencerkan dengan asam oksalat $1 \%$ hingga $10 \mathrm{~mL}$ dan dihomogenkan. Konsentrasi larutan standar 1000 ppm asam askorbat yakni 50, 60, 70, 80, 90, dan 100 ppm.

\section{Penentuan Panjang Gelombang Maksimum ${ }^{6}$}

Panjang gelombang maksimum diperoleh melalui pengukuran absorbansi dari larutan standar asam askorbat pada konsentrasi $70 \mathrm{ppm}$. Dari larutan tersebut diambil sebanyak $1 \mathrm{~mL}$ kemudian dicampurkan dengan 1 $\mathrm{mL}$ dapar fosfat $0,2 \mathrm{M}(\mathrm{pH} \mathrm{6,6)}$ dan 1 $\mathrm{mL}$ kalium ferrisianida $1 \%$, campuran 
Analisis aktivitas antioksidan sediaan propolis yang beredar di kota makassar dengan metode FRAP (Ferric Reducing Antioxidant Power)

diinkubasi pada $50^{\circ} \mathrm{C}$ selama 20 menit. Setelah selesai diinkubasi ditambahkan $1 \mathrm{~mL}$ larutan asam trikloroasetat, selanjutnya disonikator. Dipipet sebanyak $1 \mathrm{~mL}$ ditambah dengan $1 \mathrm{~mL}$ aquades dan $0,5 \mathrm{~mL}$ $\mathrm{FeCl}_{3} \quad 0,1 \%$. Larutan didiamkan selama 10-15 menit dan ukur absorbansinya pada setiap panjang gelombang dalam kisaran 650-730 nm dengan menggunakan spektrofotometer UV-Vis.

\section{Uji Aktivitas Antioksidan pada Sampel Propolis}

Larutan stok dibuat dengan konsentrasi 1000 ppm pada sampel propolis $A, B$, dan $C$ yaitu dengan cara menimbang sampel masingmasing sebanyak $25 \mathrm{mg}$ dan dilarutkan dengan etanol $96 \%$ sambil diaduk dan dihomogenkan lalu cukupkan volumenya hingga $25 \mathrm{~mL}$.

Selanjutnya sampel propolis A, $B$, dan C, dari masing-masing konsentrasi di pipet $1 \mathrm{~mL}$ dicampurkan dengan $1 \mathrm{~mL}$ dapar fosfat $0,2 \mathrm{M}(\mathrm{pH}$ 6,6) dan $1 \mathrm{~mL}$ kalium ferrisianida $1 \%$, campuran diinkubasi pada $50^{\circ} \mathrm{C}$ selama 20 menit. Setelah selesai diinkubasi ditambahkan $1 \mathrm{~mL}$ larutan asam trikloroasetat, selanjutnya disonikator. Dipipet sebanyak $1 \mathrm{~mL}$ ditambah dengan $1 \mathrm{~mL}$ aquades dan $0,5 \mathrm{~mL} \quad \mathrm{FeCl}_{3} \quad 0,1 \%$. Larutan didiamkan selama 10-15 menit dan ukur absorbansinya pada $\lambda$ maks 710 $\mathrm{nm}$ dengan spektrofotometer UV-Vis. Nilai FRAP dinyatakan $\mathrm{mg}$ equivalen asam askorbat / mg sampel.

\section{HASIL PENELITIAN}

Tabel 1. Hasil pengukuran absorbansi larutan pembanding asam askorbat pada $\lambda$ maks $710 \mathrm{~nm}$

\begin{tabular}{cc}
\hline Konsentrasi (ppm) & Absorbansi (nm) \\
\hline 50 & 0,286 \\
60 & 0,373 \\
70 & 0,480 \\
80 & 0,566 \\
90 & 0,633 \\
100 & 0,705 \\
\hline
\end{tabular}


Analisis aktivitas antioksidan sediaan propolis yang beredar di kota makassar dengan metode FRAP (Ferric Reducing Antioxidant Power)

Tabel 2. Hasil pengukuran absorbansi pada $\lambda$ maks $710 \mathrm{~nm}$ dan nilai aktivitas antioksidan pada sampel propolis $A$

\begin{tabular}{cccc}
\hline $\begin{array}{c}\text { Sampel Propolis } \\
\text { A }\end{array}$ & $\begin{array}{c}\text { Absorbansi } \\
(\mathbf{7 1 0} \mathbf{~} \mathbf{m})\end{array}$ & $\begin{array}{c}\text { Aktivitas Antioksidan } \\
\text { (mgAAE/mg sampel) }\end{array}$ & $\begin{array}{c}\text { Aktivitas Antioksidan } \\
\text { Rata-Rata (mgAAE/mg } \\
\text { sampel) }\end{array}$ \\
\hline Replikasi 1 & 0,690 & 0,0961 & \\
Replikasi 2 & 0,700 & 0,0973 & 0,0971 \\
Replikasi 3 & 0,704 & 0,0978 & \\
\hline
\end{tabular}

Tabel 3. Hasil pengukuran absorbansi pada $\lambda$ maks $710 \mathrm{~nm}$ dan nilai aktivitas antioksidan pada sampel propolis B

\begin{tabular}{cccc}
\hline $\begin{array}{c}\text { Sampel Propolis } \\
\text { B }\end{array}$ & $\begin{array}{c}\text { Absorbansi } \\
(\mathbf{7 1 0} \mathbf{~ n m})\end{array}$ & $\begin{array}{c}\text { Aktivitas Antioksidan } \\
\text { (mgAAE/mg sampel) }\end{array}$ & $\begin{array}{c}\text { Aktivitas Antioksidan } \\
\text { Rata-Rata (mgAAE/mg } \\
\text { sampel) }\end{array}$ \\
\hline Replikasi 1 & 0,428 & 0,0653 & \\
Replikasi 2 & 0,436 & 0,0663 & 0,0669 \\
Replikasi 3 & 0,460 & 0,0691 & \\
\hline
\end{tabular}

Tabel 4. Hasil pengukuran absorbansi pada $\lambda$ maks $710 \mathrm{~nm}$ dan nilai aktivitas antioksidan pada sampel propolis $\mathrm{C}$

\begin{tabular}{cccc}
\hline $\begin{array}{c}\text { Sampel Propolis } \\
\text { C }\end{array}$ & $\begin{array}{c}\text { Absorbansi } \\
\mathbf{( 7 1 0 ~} \mathbf{~ n m})\end{array}$ & $\begin{array}{c}\text { Aktivitas Antioksidan } \\
\text { (mgAAE/mg sampel) }\end{array}$ & $\begin{array}{c}\text { Aktivitas Antioksidan } \\
\text { Rata-Rata (mgAE/mg } \\
\text { sampel) }\end{array}$ \\
\hline Replikasi 1 & 0,289 & 0,0489 & \\
Replikasi 2 & 0,291 & 0,0492 & 0,0493 \\
Replikasi 3 & 0,296 & 0,0498 & \\
\hline
\end{tabular}

\section{PEMBAHASAN}

Propolis atau lem lebah merupakan suatu bahan resin yang dikumpulkan oleh lebah madu dari berbagai macam jenis tumbuhan. Propolis telah digunakan sejak dahulu kala sebagai obat tradisional, yaitu menyembuhkan kulit yang luka, infeksi pada mulut, pengobatan kanker, bronkhitis, asma, pengobatan prostat daerah jantung dll. Penelitian dibidang kesehatan terhadap propolis telah banyak dilakukan luar negri, baik secara in vitro maupun in vivo.
Hasilnya menunjukkan bahwa propolis memiliki beberapa aktivitas biologis dan farmakologis, salah satu diantaranya propolis bersifat antioksidan karena mampu menangkap radikal bebas. ${ }^{7,8}$

Penelitian ini bertujuan untuk menentukan aktivitas antioksidan yang ada pada sampel produk cair propolis. Kemampuan suatu ekstrak tanaman sebagai antioksidan dapat diwakili dengan suatu besaran TAC (Total Antioxidant Capacity). TAC adalah kapasitas antioksidan kumulatif yang 
Analisis aktivitas antioksidan sediaan propolis yang beredar di kota makassar dengan metode FRAP (Ferric Reducing Antioxidant Power)

terdapat dalam suatu sampel tanpa menunjukkan jenis senyawa aktifnya. Penentuan TAC dilakukan dengan metode FRAP. ${ }^{9}$

Pengujian aktivitas antioksidan metode FRAP mengikuti prosedur dari Yen dan Chen $(1995)^{7}$ yang dimodifikasi dari prosedur Oyaizu (1986) dengan menggunakan kompleks kalium ferrisianida $\left(\mathrm{K}_{3} \mathrm{Fe}(\mathrm{CN})_{6}\right) \cdot{ }^{10}$ Dalam penentuan daya reduksi, reduktor (antioksidan) dalam sampel yang mereduksi $\mathrm{Fe}^{3+}$ kompleks kalium ferrisianida $\left(\mathrm{K}_{3} \mathrm{Fe}(\mathrm{CN})_{6}\right)$ menjadi $\mathrm{Fe}^{2+}$ (bentuk ferro). ${ }^{11}$ Reaksinya adalah sebagai berikut:

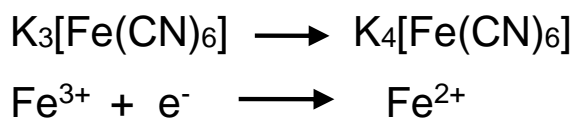

Metode FRAP meliputi tahap pembuatan reagen FRAP, pembuatan larutan standar, penentuan panjang gelombang maksimum, dan pengukuran total antioksidan dalam sampel menggunakan alat spektrofotometer UV-VIS.

Sebelum dilakukan pengujian aktivitas antioksidan terlebih dahulu dilakukan penentuan panjang gelombang maksimum yang akan digunakan dalam mengukur absorbansi dari larutan standar dan larutan sampel. Larutan standar yang digunakan adalah asam askorbat.
Asam askorbat digunakan sebagai pembanding karena memiliki gugus hidroksil bebas yang bertindak sebagai penangkap radikal bebas dan jika mempunyai gugus polihidroksil akan meningkatkan aktivitas antioksidan. ${ }^{12}$

Penentuan panjang gelombang maksimum dilakukan pengukuran panjang gelombang dari $650-730 \mathrm{~nm}$. Kemudian diperoleh panjang gelombang maksimal $710 \mathrm{~nm}$. Dari masing-masing konsentrasi larutan standar 50, 60, 70, 80, 90, dan 100 ppm diukur absorbansinya pada panjang gelombang $710 \mathrm{~nm}$, kemudian dari data absorbansi yang di dapat akan dibuatkan persamaan garis linear yang nantinya digunakan untuk menghitung aktivitas antioksidan.

Selama proses pengerjaan dilakukan penambahan TCA yang bertujuan agar kompleks kalium ferrisianida mengendap. Penambahan $\mathrm{FeCl}_{3}$ dalam reagen yaitu untuk membentuk senyawa kompleks berwarna hijau sampai biru (biru berlin). Sedangkan penambahan buffer fosfat adalah karena buffer ini memiliki pH efektif 6,4-7,4. Dimana telah diketahui bahwa kompleks ini stabil pada $\mathrm{pH}$ asam, maka digunakan $\mathrm{pH}$ 6,6 dalam penelitian ini. Penggunaan $\mathrm{pH}$ rendah dimaksudkan 
Analisis aktivitas antioksidan sediaan propolis yang beredar di kota makassar dengan metode FRAP (Ferric Reducing Antioxidant Power)

untuk memudahkan proses reduksi $\mathrm{Fe}^{3+}$. Hasil regresi dari konsentrasi $(x)$ dengan nilai absorbansi $(\mathrm{y})$ standar asam askorbat diperoleh persamaan yaitu $y=0,0085 x-0,1273$ dengan nilai $R^{2}=0,9934$ dan absorbansi dimasukkan ke persamaan tersebut. Pada sampel propolis A diperoleh data absorbansi replikasi I 0,690, replikasi II 0,700, dan replikasi III 0,704. Pada sampel propolis $\mathrm{B}$ diperoleh data absorbansi replikasi I 0,428, replikasi II 0,436 , replikasi III 0,460. Pada sampel propolis $\mathrm{C}$ diperoleh data absorbansi replikasi | 0,289, replikasi || 0,291, replikasi III 0,296. Dan hasil pengukuran secara kuantitatif didapatkan kapasitas antioksidan yang ekuivalen dengan asam askorbat yaitu untuk sampel propolis A sebesar 0,0971 mgAAE/ mg sampel, pada sampel propolis B sebesar 0,0669 mgAAE/mg sampel, dan pada sampel propolis $\mathrm{C}$ sebesar $0,0493 \mathrm{mgAAE} / \mathrm{mg}$ sampel.

Dari data yang diperoleh dapat disimpulkan bahwa semakin besar kandungan ekstrak propolis dalam sediaan tidak menjamin tingginya aktivitas antioksidan dalam sampel tersebut. Hal ini dikarenakan adanya zat-zat tambahan yang ada pada sampel.
Metode FRAP digunakan untuk mengukur kemampuan antioksidan dalam mereduksi $\mathrm{Fe}^{3+}$ menjadi $\mathrm{Fe}^{2+}$ dengan peningkatan nilai absorbansi menunjukkan besarnya aktivitas antioksidan dari sampel yang diuji.

\section{KESIMPULAN}

Dari hasil pengujian aktivitas antioksidan pada sedian propolis yang beredar di Kota Makassar menggunakan metode FRAP diperoleh aktivitas antioksidan pada sampel $A$ 0,0971 $\mathrm{mgAAE} / \mathrm{mg}$ sampel, pada sampel $B$ sebesar 0,0669 mgAAE/mg sampel, dan pada sampel $C$ sebesar 0,0493 mgAAE/mg sampel.

\section{DAFTAR PUSTAKA}

1. Novilla A. Aktivitas Antioksidan Ekstrak Propolis Lebah Madu Lokal Apis mellifera. Jurnal Kesehatan Kartika. 2011;8:64-72.

2. Halim E, Hardinsyah, Sutandyo N, Sulaeman A, Artika M, Harahap Y. Kajian Bioaktif dan Zat Gizi Propolis Indonesia dan Brasil. Jurnal Gizi Dan Pangan. 2012;7(1):1-6.

3. Bankova VS, de Castro SL, Marucci MC. Propolis: Recent Advances in Chemistry and Plant Origin. Apidologie.2000;31:3-15.

4. Saharudin. Analisis Aktivitas Antioksidan Produk Cair Propolis yang Beredar di Kota Makassar dengan Metode DPPH (Skripsi). Makassar: Fakultas Farmasi, Universitas Muslim Indonensia,2014. 
Analisis aktivitas antioksidan sediaan propolis yang beredar di kota makassar dengan metode FRAP (Ferric Reducing Antioxidant Power)

5. Chew YL, Lim YY, Omar M, Khoo KS. Antioxidant Activity Of Three edible seaweeds from two areas in South East Asia. LWT 41. 2008 : $1067-1072$.

6. Yen G, Chen CHY. Antioxidants Activity of Various Tea Extracts in Relation to Their Antimutagenicity. J Agric Food Chem.1995;43: 383386.

7. Sabir A. Respons Inflamasi pada Pulpa Gigi Tikus Setelah Aplikasi Ekstrak Etanol Propolis (EEP). Maj Ked Gigi. 2005;38(2):77-83.

8. Sabir A. Aktivitas Antibakteri Flavonoid Propolis Trigona $s p$ Terhadap Bakteri Streptococcus mutans (in vitro). Maj Ked Gigi.2005;38(3):135-141.

9. Istiningrum RB. Analysis of Total Antioxidant Capacity on Ingredientsof Lotek Menu by Ferric
Reducing Antioxidant Power Assay. Eksakta. 2013;13(1-2):4048.

10. Ou B, Huang D, Woodill MH, Flanagan JA, Deemer EK. Analysis of Antioxidant Activities of Common Vegetables Employing Oxygen Radical Absorbance Capacity (ORAC) and Ferric Reducing Antioxidant Power (FRAP), J Agric Food Chem. 2002;50:3122-3128.

11. Safriani N, Normalina A, Mehra E. Potensi of Curry (Murayya koeniigi) and salam (Eugenia polyantha) Leaves as Natural Antioxidant Sources. Pakistan Journal of Nutrition. 2015;14(3):131-135.

12. Isnindar, Wahyuono S, Erna PS. Isolasi dan Identifikasi Senyawa Antioksidan Daun Kesemek (Diospyros kaki Thunb.) dengan metode DPPH. Majalah Obat Tradisional. 2011;16(3):157-164. 